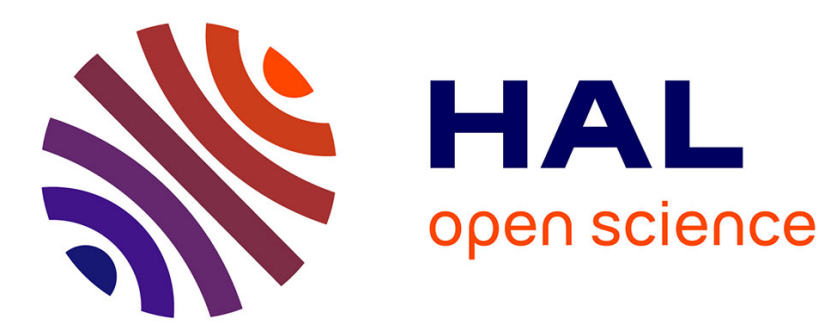

\title{
Prayer as a Tool in Swedish Pentecostalism
}

\author{
Emir Mahieddin
}

\section{To cite this version:}

Emir Mahieddin. Prayer as a Tool in Swedish Pentecostalism. Sociology of prayer, 2015. halshs02423943

\section{HAL Id: halshs-02423943 \\ https://shs.hal.science/halshs-02423943}

Submitted on 23 Oct 2020

HAL is a multi-disciplinary open access archive for the deposit and dissemination of scientific research documents, whether they are published or not. The documents may come from teaching and research institutions in France or abroad, or from public or private research centers.
L'archive ouverte pluridisciplinaire HAL, est destinée au dépôt et à la diffusion de documents scientifiques de niveau recherche, publiés ou non, émanant des établissements d'enseignement et de recherche français ou étrangers, des laboratoires publics ou privés. 


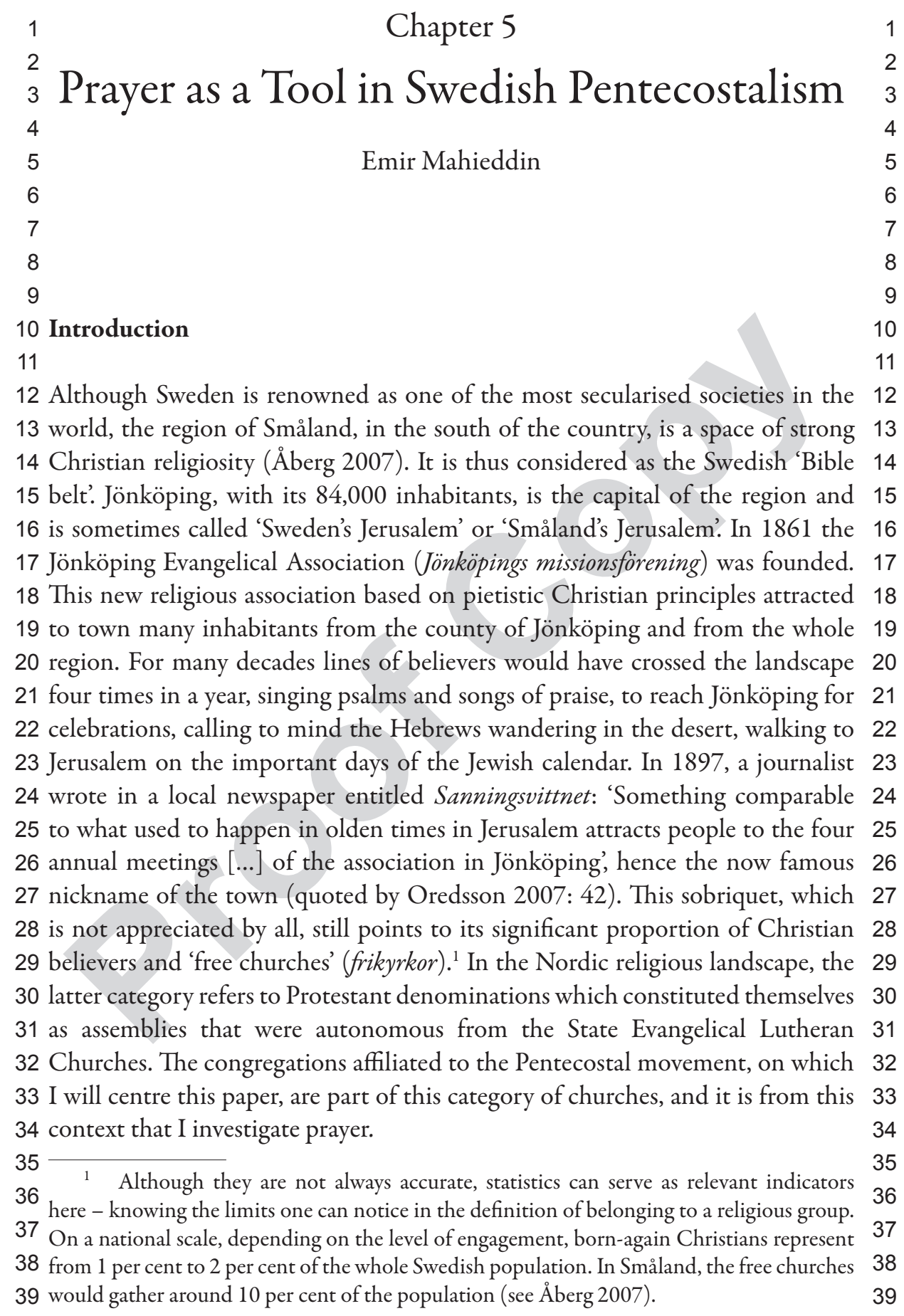


1 In the first part of the paper I will explore ethnographic data I have gathered 1

2 concerning the stylistic variations observed in Swedish Pentecostal prayer at 2

3 different moments of religious life. These variations point to a sharp contrast 3

4 between two spaces of Christians lives which were symbolically constructed as 4

5 a public space on the one hand, when it comes to Sunday services; and, on the 5

6 other hand, as a private space, when it comes to the so called 'cell groups' and 6

7 individual prayers. In the second part, I propose an analysis of these contrasted 7

8 behaviours, referring to contextual data and to individual and collective 8

9 discourse, which allows understanding and/or explaining, at least partially, what 9

10 appears at first sight as a sort of 'decharismatization' of Swedish Pentecostalism, 10

11 starting three decades ago. Finally, in the third and last part, I try to demonstrate 11

12 how a socio-anthropological study of prayer permits us to draw a certain set of 12

13 conclusions on the dynamics of symbolic production in the Swedish evangelical 13

14 milieu, and, at the same time, to have a general idea of what praying means to the 14

15 religious subject, in the frame of his/her relationship to an invisible being - in 15

16 this case Jesus Christ. In brief, my aim is to investigate contemporary mutations 16

17 of prayer in Swedish Pentecostalism. In what way did it change? On what sorts 17

18 of mechanisms are these mutations based? What sense do they have in their 18

19 cultural configuration of emergence? What can the observation of prayer teach 19

20 us about the Swedish context? And above all, as it is our concern in this volume, 20

21 what can the analysis of the mentioned mutations, and of the existential posture 21

22 of the praying subject, teach us about prayer itself, as a social and cultural fact? 22

25 The Swedish Pentecostals: Joshua's Generation 25

27 Pentecostalism - or 'Pentecostalisms', if one is allowed to put the word in a 27

28 plural form, as it was suggested by André Corten and André Mary (2000) - is 28

29 renowned for its focus on the bodily experience of the Holy Spirit while praying, 29

30 giving space to the manifestation of charismata (spiritual gifts) during services. 30

31 Prophecies, visions, healing and speaking in tongues are gifts from the Spirit, 31

32 as described in the second chapter of the Acts of the Apostles, and specific 32

33 features of Pentecostal liturgy. Thus, Pentecostal Christians often pray in 33

34 tongues, or glossolalia, this 'tongue of fire' - or 'tongue of the Spirit' - which 34

35 allows worshippers to communicate with God in an ideal order of ineffability. 35

36 Thus the Swedish Pentecostal movement had been called in its early days in the 36

37 1910s 'tongue movement' (tungotalrörelse) and its followers were often referred 37

38 to by their detractors as 'tongue speakers' (tungotalare). From the language of 38

39 words to body language, Pentecostals are also famous for their ecstatic corporal 39 
1 manifestations throughout their meetings and collective prayer moments. 1

2 During these, some individuals see their body shivering under the power of 2

3 the Spirit striking them. And as they were called 'tongue speakers', they were 3

4 also referred to by the deprecatory term 'shakers' (skakare). ${ }^{2}$ The effusion of 4

5 charismata leads some worshippers to 'fall into the Spirit', as the expression 5

6 says, which literally means that individuals tumble to the ground during an 6

7 intercession prayer, overwhelmed by the Holy Ghost. Many ethnographic 7

8 descriptions of Pentecostal worship mention these facts all over the world (see 8

9 among others Hollenweger 1972; Cox 2001; Corten and Mary, op.cit.; Corten 9

10 and Marshall-Fratani 2001). 10

11 It is therefore surprising that one cannot observe these things in the Swedish 11

12 Pentecostal assemblies, either the classical movement or the more recent 12

13 charismatic forms, including the Vineyard movement - even though the latter 13

14 is famous for having given birth to the Toronto blessing in 1994 which initiated 14

15 new spiritual manifestations such as laughing out loud, crying, or even shouting 15

16 animal sounds, and several moments of collective effervescence characterised 16

17 by an intense exteriorisation of religious emotions. ${ }^{3}$ Indeed, a Sunday worship 17

18 visitor in a Swedish church will be struck by the absence of such charismatic 18

19 demonstrations, though they are supposed to be proper to the Churches 19

20 claiming to be Pentecostal. Prayers are often led by the pastor, or by an elder, 20

21 in front of a surprisingly calm audience, in which only certain individuals dare 21

22 express themselves 'out loud', though in a cautious whisper, with contained and 22

23 controlled bodily gestures. 23

24 It is more often in the prayer cell groups, ${ }^{4}$ which slowly became the private 24

25 sphere of Pentecostalism because of their constitution out of mutual affinities, 25

26 that charismata find a fuller expression. Sometimes, it is in the privacy of a 26

27 conversation with a friend that one shares prophecies and visions, or in the 27

28 context of an intercessory prayer that a person feels the Spirit invading him/ 28

29 her powerfully. Beyond that, some Christians will only speak in tongues in the 29

30 intimacy of a personal exchange with God, in the solitary presence of the Lord, 30

31 while praying in their bedroom or driving their car. 31

32 Swedish Pentecostalism has not always been like it is today. During the coffee 32

33 time or during meetings, I often heard Christians referring, in a nostalgic tone 33

34

352 The movement was also referred to as 'The new revival' (den nya väckelsen), about 36 this see Sundstedt 1969.

$37 \quad 3$ Note that the church of Toronto was excluded from the Vineyard movement because

37 of the controversial dimension of these manifestations.

$38{ }_{4}$ For a detailed history of cell groups, see David Hunsicker (1996). 'John Wesley:

39 Father of Today's Small Group Concept?'. In Wesleyan Theological Journal 31/1: 192-211. 
1 or not, to a period when prophecies popped out here and there in the assembly, 1

2 people spoke in tongues, and miracles were common. Nowadays, some of them 2

3 regret that the meetings became 'boring', lacking surprise or divine presence. 3

4 They wish to go back to the 'good old time'. Among these nostalgic people is 4

5 Patrick, a young enthusiastic Pentecostal I met in a prayer group, who converted 5

6 at the end of adolescence. The first time I saw him, he was warning his fellows 6

7 against the routine they settled into in their relationship with God. In prophetic 7

8 terms, he calls his generation 'Joshua's generation'. According to him, his 8

9 generation of Pentecostals is the third since the first awakening at the beginning 9

10 of the century in 1906, and it has not known the founding moments like the 10

11 first converts', which he compares to Moses' generation, when the Hebrews 11

12 fled from Egypt. The third generation consists of the people who will remain 12

13 after all the non-believers of the second generation leave because of their lack of 13

14 faith, subsequent to their involvement in a church motivated by tradition. 'They 14

15 practice because of their parents but do not know what it really is to believe', says 15

16 Patrick. He adds: 'these will soon leave the church of their parents, as the sons 16

17 of the first Hebrews in the desert who preferred being devoted to the Golden 17

18 Calf, and only the chosen ones will remain'. Patrick interprets this calm in the 18

19 contemporary Swedish Pentecostal liturgy as a lack of enthusiasm in faith of the 19

20 second generation of Pentecostals, a calm that will soon be over. 20

21 But how did Swedish Pentecostalism get to this situation? How was this 21

22 'second generation' born, to refer to the terms used by Patrick? And what led it to 22

23 change the liturgical aspects of the Pentecostal church? To answer these questions, 23

24 I will mainly refer to national elements of historical and political context. Indeed, 24

25 Pentecostalism observed in other contexts, including Africa or Latin America, 25

26 offers the classical features of a Pentecostal or Charismatic Church. Its liturgy is 26

27 even sometimes characterised as 'violent' by anthropologists (see Mary 2000), 27

28 and public healing, prophesy or speaking in tongues is still common. 28

$29-29$

$30 \quad 30$

31 The Reasons for a 'Decharismatization' 31

$32 \quad 32$

33 It is difficult to date precisely the beginning of the 'decharismatization' (the 33

34 progressive disappearance of charismata) of Sunday worship in Sweden. It is a 34

35 result of a long process that probably extends throughout the whole second half 35

36 of the twentieth century. But we can note a breaking point which started an 36

37 acceleration of that process at the beginning of the 1980s with the emergence 37

38 of the Faith movement, a trans-denominational movement influenced by the 38

39 Gospel of prosperity, of which the famous Word of Life (Livets Ord), studied 39 
1 by the British anthropologist Simon Coleman (2007), ${ }^{5}$ was an organisational 1

2 manifestation (see Aronsson 2005). Very present, active and expert in the use 2

3 of media technology, this assembly, and its leader Ulf Ekman, quickly attracted 3

4 public opinion, which expressed its disapprobation through terms characteristic 4

5 of allegations against so-called 'sectarian movements' (brainwashing, money 5

6 extortion from believers who are victims of their own naivety, blind trust in a 6

7 charismatic leader). This disapproval was also rooted in the effervescence of the 7

8 Word of Life worship where the believers, as well as the preachers, expressed 8

9 themselves in tongues and were slain in the Spirit. 9

10 Nowadays, even if the Word of Life remains the most charismatic 10

11 denomination in the Swedish religious marketplace - we still hear speaking in 11

12 tongues and can observe a few individuals shaking and jumping on the spot as 12

13 they used to in the past - their liturgical style has 'cooled down', experiencing 13

14 a similar process to the one experienced by classical Pentecostalism in Sweden, 14

15 although it happened within a much shorter period of time. But because of 15

16 the bad reputation of Word of Life in its early years and up to the 1990 s, some 16

17 'classical' Pentecostals told me they felt compelled to act with discretion to avoid 17

18 being related to Ulf Ekman's controversial movement by public opinion. This 18

19 effect was made stronger because of the double affiliation of many followers, who 19

20 still occasionally visited the Sunday services in their more classical Pentecostal 20

21 church of origin (Pingstkyrkan). ${ }^{6} \quad 21$

22 But why was Swedish opinion disturbed by the charismatic practices, and why 22

23 did the Pentecostals react as they did, deciding not to deploy as much charismata 23

24 as they used to and 'disciplining' their bodies during the Sunday service? Was 24

25 the appearance of a more charismatic dissident church in the religious landscape 25

26 the only reason? Or did it just highlight broader dynamics? 26

27 The explanation is probably related to the specificity of the Swedish religious 27

28 configuration, dominated over centuries, and still today, by the Evangelical 28

29 Lutheran Church, which was the state Church up to 1 January 2000. The salience 29

30 of this type of Church in the Nordic countries is well recognised by sociologists 30

31 of religion. It is the main provider of all the rites of passage in life, and a majority 31

32 of Swedes (around 70 per cent in 2010) ${ }^{7}$ remain members of a Church, even 32

33 when declaring themselves non-believers. Many are still baptised ( 50 per cent 33

34 of all newborn children in 2010), confirmed, married and buried in accordance 34

365 See also Coleman 1989, 1996, 2006 and Gifford 2001.

376 See Coleman 2007, who explains he met Pentecostals who still went to both groups

37 (ibid.: 188). The author describes as well how the bodily practices of « Word of Lifers »

38 betrayed the double belonging of these believers, generally among youngsters.

397 Svenska kyrkans medlemutveckling år 1972-2010. www.svenskakyrkan.se. 
1 with Christian ritual. This seems to be an illustration of the 'belonging without 1

2 believing' which is one of the main characteristics of Nordic religiosity. Thus, 2

3 although a lot of Swedes claim to be non-believers, ${ }^{8}$ a large majority of them 3

4 benefit from a socialisation into Lutheran religiosity (when they are themselves 4

5 involved in the ritual of course, but mostly as spectators of rituals; from their 5

6 early years to the last day of their life). 6

7 Thus the style of such state-church religiosity, renowned for its sobriety and 7

8 its silence, contributes directly to a public representation of what is 'religiously 8

9 correct' in Sweden. Besides, inspired by a liberal and 'rationalising' theology 9

10 (clergymen contributed to excising magical or supernatural content from 10

11 Christian practices), national Lutheranism contrasts, in its dogma and liturgy, 11

12 with the religious offer of its Pentecostal competitors. More than defining the 12

13 prevalent frame of religious socialisation in the country, the Lutheran Church 13

14 was also, over a long period, a major political institution that played an important 14

15 part in education for all the inhabitants of Sweden, notably through the national 15

16 schooling system. Indeed, the oldest Pentecostals I have met remembered praying 16

17 every morning before class and following religious teaching at school during 17

18 their childhood. As a result, the evangelical-Lutheran Church of Sweden acts as 18

19 a centripetal force that still influences the religious field by its magnetism, still 19

20 benefitting from a monopolistic situation from which pertained until recently 20

21 in the national history. 21

22 Swedish Pentecostals themselves seldom speak of the 'supernatural' ${ }^{9}$ during 22

23 the Sunday service, and appear to be a somewhat liberal movement compared to 23

24 their counterparts in other countries. Similarly, female ministry is an accepted 24

25 fact and the management of sin does not follow repressive and communitarian 25

26 logics anymore - in contrast to what could have been adopted earlier, namely 26

27 before the turn of the 1960-70s (evoked elsewhere as a major shift for all the 27

28 European societies). This repressive approach could lead to some worshippers 28

29 accused of sinning (consuming tobacco or alcohol, divorcing, etc. according to 29

30 the metaphorical 'catalogue of $\sin ^{\text {' }}{ }^{10}$ as Pentecostals call it) to be expelled from 30

31 their congregation. Nowadays this part of the Pentecostal history is harshly 31

32 criticised by a major part of Swedish Pentecostals and by the direction of the 32

33 church, with regret expressed that their predecessors had failed in understanding 33

34 and truly applying the message of the Gospels. The latter are broadly considered 34

35 nowadays in the movement as a message of love and forgiveness, as demonstrated 35

$36 \longrightarrow 36$

$\begin{array}{lll}37 & 8 & \text { According to the surveys, only } 10 \text { per cent of Swedes claim to believe in a personal } 37\end{array}$

38 God (source: www.eurel.info).

$38 \quad$ Det övernaturliga in Swedish. This notion is used by the actors themselves. $\quad 38$

$39 \quad 10$ Syndakatologen in Swedish. 
1 by Christ Himself towards sinners. Christians are instructed to act as a little 1

2 Christ', to quote an expression used by Simon Coleman (2007), and to adopt 2

3 towards their fellows the attitude that the Messiah had towards His. The first 3

4 concern is that anyone should feel warmly welcome because everyone has a 4

5 place close to God. Thus, it is often said in sermons that the 'Lord used sinners 5

6 to do His will, from Jacob who lied to his own father, to Moses who went as 6

7 far as committing a homicide'. The idea is that everyone can represent Christ 7

8 to one's fellows through examplification (see Piette 1999: 76-7). The aim is to 8

9 accomplish the worldly work of God (Tonda 2002), whose social mediators are 9

10 the Christians and their community. ${ }^{11} \quad 10$

11 It is because everyone ought to feel welcome in Church that the Sunday 11

12 service progressively turned into a public space in which anyone, that is to say 12

13 non-believers as well, could be expected. One piece of evidence for this is the 13

14 particular attention given to the prospective visitor, who hears him or herself 14

15 addressed in the same words every Sunday: 'May the people who are here for 15

16 the first time feel warmly welcome and live with us a glad moment of worship!'. 16

17 Sometimes, I also heard people telling me that they did not want to speak in 17

18 tongues out loud on Sunday as it might frighten the potential newcomers who 18

19 are not familiar with the gifts of the Spirit.

20 Recent state policies have also established new relationships between free 20

21 churches and political institutions, setting new elements which implicitly 21

22 encouraged the latter to change. In 2000, the parliament implemented separation 22

23 between the state and the Lutheran church. At the same time, a law was passed 23

24 which gave a new status to free churches, all of which were considered religious 24

25 associations, thus earning the right to receive public funds (see Harry 2010). 25

26 The fund is distributed in accordance with the size of the denomination. As 26

27 such, the Pentecostal movement received around seven million Swedish crowns 27

28 in $2010 .^{12}$ The amount is not a lot compared with the actual finances of the 28

29 Pentecostal movement, ${ }^{13}$ but it changed the logic of the churches' relation to 29

$30 \longrightarrow 30$

$31 \quad 11$ The use of this expression, suggested by the anthropologist Joseph Tonda (2002), could be seen as a new surrender by social scientist to the demon of analogy, thus comparing

32 religion to a work, but Christians use this expression themselves (they also speak about

33 the 'workers of God'). Tonda defines this Work of God as a process of transformation of a

34 whole 'culture' or the 'society', a set of physical, linguistic and material practices which aim at 35 producing and reproducing symbolic goods.

$36 \quad 12$ See H. Boström's article in the Swedish Christian newspaper Dagen: 'Så mycket får 37 samfunden i statsbidrag', 11 May, pp. 6-7.

3713 In 2010, the donations of the adherents went up to $335,285,311$ Swedish crowns

38 (statistics produced by the church, document online http://www.pingst.se/viewNavMenu.

39 do?menuID=71). The Pentecostals also get State funding through their organisation $P M U$ 32 33 34 35 36 38 39 
1 the state and to surrounding society. It gave a new legitimacy to observing and 1

2 criticising what happens, what is said, and what is thought in the churches (as a 2

3 financial contributor). The mixture of this new relation to the Swedish state and 3

4 the increasing media sphere since the beginning of the 1980s, combined with 4

5 the concern of Pentecostals to gain credibility, has therefore resulted in powerful 5

6 constraints causing the progressive disappearance of charismata in favour of a 6

7 calmer way to signify the presence of the Lord in public. In private, however, 7

8 the gaze of outside society being absent, glossolalia and other charismata can be 8

9 uttered without any problem. ${ }^{14} 9$

10 Another sociological phenomenon reinforces this situation: the experiment 10

11 of glossolalia as a spiritual impulse. If speaking in tongues is the result of a process 11

12 of religious socialisation, that is to say a learning process, it does not imply that 12

13 one can fully control it. ${ }^{15}$ 'We cannot speak in tongues on command, it just 13

14 comes out!' a worshipper told me. Another one explained that he felt a sort of 14

15 'need' to speak in tongues, an 'urge' he almost experienced as a necessity during 15

16 prayer. Managing this spiritual gift, unequally distributed between private and 16

17 public spheres, thus appears to be part of a kind of economy of impulses, to quote 17

18 the sociologist Norbert Elias (1973). One could even think of it as taking place 18

19 in an economy of affects given the emotional dimension of its manifestation. 19

20 Therefore, it is relevant to analyse its deployment by interpreting it according to 20

21 its socio-cultural context of inscription. 21

22 This dimension emerges clearly in the comparative work conducted by 22

23 the sociologist Flavio Munhoz Sofiati, who observed contrasting behaviours 23

24 concerning the manifestation of the Spirit, thus differentiating French and 24

25 Brazilian charismatic Catholic styles of worship. The first favour a corporal 25

26 form of meeting with the Spirit in their prayer group, while the second prefer to 26

27

28 Interlife in order to achieve development programmes in the Third World and in Eastern 28

29 Europe.

$30 \quad{ }^{14}$ The cell groups which constitute the private sphere are not always a place where one 30

31 can observe the utterance of glossolalia. Jenny, a Pentecostal lady, told me they had stopped

speaking in tongues in prayer when receiving new believers who had not experienced baptism

32 in the Spirit yet.

33 is Everybody might not agree on the possibility to learn glossolalia but some pastors

34 inside the Pentecostal movement assert that it can be taught and learnt (see Cox 2001). For

35 my part, I met Pentecostals telling that they practised speaking in tongues (once they had

36 been baptised in the Spirit) in their car, or, for the case of one woman who was frightened

37 by her own utterances, on her bike, so that the wind blowing on her ears would prevent her

37 from hearing what she was saying. The statements can seem contradictory, that speaking can

38 be trained and that it is an impulse, but maybe this kind of training could be compared to

39 laughing yoga, where the impulse is provoked by repetitive tries to start laughing. 
1 manifest their meeting with God verbally through glossolalia. ${ }^{16}$ Both constitute 1

2 different manners of expressing the presence of God through a given state of the 2

3 bodies or a modification of language, thus expressing two types of sensitivity. 3

4 Similarly, the depiction of Polynesian Pentecostals by the anthropologist 4

5 Yannick Fer tends to present the latter as developing an inverse model to the 5

6 Swedish one, privileging glossolalia in public and silent devotion in the intimacy 6

7 of private prayers. More than an impulse, this tongue of prayer (bönespråk) given 7

8 by God is the expression of the deepest spiritual individuality of the believer; 8

9 the one in which the ineffable is communicated, the unspeakable request can 9

10 be transmitted, and through which one builds one's personal relationship to the 10

11 Lord. Such a manifestation is thus relegated behind the curtains of privacy as if 11

12 it were impudent to show the deep 'inside' of the self. 12

13 Considering this emotional dimension of charismata does not imply that we 13

14 must think of them as primal utterances of given natural impulses. The product 14

15 of socialisation, the emotional dimension - and even its impulsive dimension - 15

16 is the result of a social construction (which does not mean it is not real). In this 16

17 sense, we can think of this 'decharismatization' process as an observable change 17

18 of relations between the Pentecostals and the national society, through a series 18

19 of minor and major events that progressively transformed the social frame in 19

20 which the believers were rooted, defining new connections and influences in 20

21 the Swedish Pentecostal regime of emotion (see Riis and Woodhead 2010). 21

22 This regime of emotion is not Swedish per se, as a result of a pre-existing, 22

23 and supposedly everlasting, reified culture. It is the result of the historical, 23

24 institutional work of the Lutheran Church which disciplined the bodies in their 24

25 churches for centuries. As one of my interlocutors stated very correctly, if one 25

26 can be scared when observing the manifestation of deep emotions at church in 26

27 Sweden, nobody seems to be affected by the same exhibitions during a football 27

28 game in the same country. In other words, it is a religious 'Swedish' regime of 28

29 emotion which was probably implemented in relation to questions of power, the 29

30 Holy Spirit, in its subversive policy (see Laurent 2000), being able to dismantle 30

31 the political unity of the State church and the legitimacy of its priests. Prayer, in 31

32 its emotional dimension, and especially when it comes to the manifestation of 32

33 the emotions it implies, is thus a political and institutional issue. 33

$34 \quad 34$

$35 \quad 35$

$36 \quad 36$

$\begin{array}{ll}37 & 37\end{array}$

$3 8 \longdiv { 1 6 }$ Munhoz-Sofiati, F., 'Comment prient les nouveaux charismatiques?'. Workshop 38

39 Sociology of Prayer, ISSR congress, Aix-en-Provence, 2 July 2011. 
1 The Aesthetics of Prayer: an Inverted Symmetric Relationship 1

2

3 Besides its potentially political dimension, prayer structures the intimate and 3 4 emotional relationship to the divine and is part of a work of self-fashioning. The 4

5 latter work aims at fashioning the believer in its attempt to make God present, thus 5

6 choosing among a finite range of mediations enabling 'externalization' (objects, 6

7 know-hows, gestures, words). ${ }^{17}$ As we saw, the style of the Pentecostal prayer is 7

8 the result of an articulation between the importance given to the charismatic 8

9 gifts and the expectations of the surrounding socio-cultural environment. 9

10 After emphasising the relationship of the believer to this environment, it is 10

11 interesting to question the modalities of the relationship to the Spirit as it is 11

12 experienced by Pentecostal believers. Not only is it partly culturally determined, 12

13 but it is also an interesting case of bonding with supernatural entities (see Pons 13

14 2011a). The Holy Spirit (and its Trinitarian corollaries, God and Jesus) acts as 14

15 a highly effective subjectivation power accompanying Pentecostals in their daily 15

16 lives. Speaking through them while they speak in tongues, the Spirit appears, 16

17 at the same time, as a tool and an interlocutor. I intend to illustrate the type of 17

18 relationship that is experienced with a supernatural entity through developing 18

19 an example I chose from my fieldwork from among many others. 19

20 Bosse is a sexagenarian entrepreneur who started his own company as an 20

21 electrician in 1972. Since the 1990s, in a parallel of his business activity, he is 21

22 involved in an NGO named Östhjälpen (literally, 'East help') that he helped 22

23 to found in Romania, some months after the fall of Ceauşescu's regime. He 23

24 considers this activity as a responsibility 'God has put in his heart'. His first visit 24

25 in the country was subsequent to a prophecy uttered by the pastor of his church, 25

26 who was married to a Romanian woman, a few weeks before the Revolution. 26

27 According to Bosse, the Lord enjoined them to go to Romania as the 'man of 27

28 Darkness was about to fall' (referring to Ceauşescu). He then evoked his first 28

29 visit to the country as the answer to a prayer made by Romanian religious fellows 29

30 eager to meet Western Christians. During his second journey there, he and an 30

31 ecumenical group of Swedish Christians met the mayor of Deva, the capital of the 31

32 region they intended to work in, in order to learn about their needs. The mayor 32

33 wanted a new orphanage for handicapped kids to be built, according to Swedish 33

34 standards. A Lutheran priest, who had travelled with the group, refused, stating 34

35 that it would be impossible to gather enough funds to lead such a project. At 35

17 Here I rely on the work of Albert Piette $(1999,2003)$ according to whom ethnography 37

38 can say that God is present in a situation as attached to reality by a range of mediations set by

39 humans in a chain, or a network of actions, know-hows, objects, etc. 
1 most, they could help with a new heating system in the existing orphanage. Bosse 1

2 got out of the meeting with a resentful feeling of disappointment. He wanted 2

3 to help the Romanians and make things change in a radical way although he 3

4 thought the priest was right not to promise something they could not guarantee. 4

5 He sat on a pavement in the streets of Deva to pray and was moved by the Spirit 5

6 in a really strong way, as he says, thus transforming his doubts and frustration 6

7 into strong conviction: 'the orphanage had to be built; it was the will of God', he 7

8 says. On the way back to Sweden, he tried to convince the priest that they had 8

9 to do it. He prayed that the Spirit would touch him as well, which eventually 9

10 happened, right before they took the ferry to cross the Baltic Sea. 10

11 The group succeeded in finding a prefabricated building in Gothenburg. 11

12 They bought it on the cheap and moved it, one piece at a time, to Romania. A real 12

13 estate agent wanted to sell it for one million Swedish crowns. But Bosse refused, 13

14 considering the price to be excessive. But 'the Spirit was at work' says Bosse, and 14

15 they could eventually buy it for 300,000 crowns, because the building was about 15

16 to be expropriated and demolished by the city hall for a renovation project. 16

17 To finance the NGO and his multiple trips to Romania, Bosse contributed to 17

18 the construction of a second-hand store in his hometown in Sweden, Pärtille. 18

19 The store was a success and fifteen jobs were created and given to unemployed 19

20 people whose income is guaranteed by the city hall. Bosse sees that as well as the 20

21 achievement of God's will. In parallel, twenty-eight jobs were created around 21

22 Östhjälpen activities in Romania and distributed to local unemployed women. 22

23 In the Pentecostal church of Jönköping, Bosse leads the morning prayer 23

24 group which gathers ten to twenty persons from eight to nine every week day. 24

$25 \mathrm{He}$ is there every single morning and is absent only when duty calls him back to 25

26 Romania where he has helped plant more than twenty churches. When evoking 26

27 his engagement and his assiduity in prayer he says: 'I am just a person observing 27

28 what God wants to do, I am commanded and I do, and one of the reasons why 28

29 I come to church every day is the burden the Lord put on my shoulder, on the 29

30 one hand for the handicapped kids for whom I am responsible, but also for the 30

31 twenty-eight employees there, for whose needs I have to provide every month 31

32 and for all the other tasks the Lord gave me ... I have to bend on my knees every 32

33 morning to stand there to observe the Lord work as he does, through me [...], I 33

34 am just a little tool in all that. The Lord has got several persons for different tasks 34

35 and he wants to use us all in different manners.

36 As we see in this example, if believers transform the way they pray to 36

37 construct the presence of a Christ corresponding to the anticipations of the 37

38 hosting society (hence the 'decharismatization'), by a dialectical logic they also 38

39 try, by the means of prayer, to transform their society. A weapon in the spiritual 39 
1 warfare between Good and Evil, as Yannick Fer put it, ${ }^{18}$ prayer is also, on a more 1

2 ordinary level, a tool in the work of God (see Tonda 2002). It helps to transform 2

3 the self on a daily basis as well as transforming the world as it is experienced by 3

4 the subject. One might pray for a parking place, for the achievement of divine 4

5 will in the Arab revolutions or, as Bosse, for help in a development programme in 5

6 Eastern Europe; in all these cases, prayer appears to the believer as an instrument 6

7 delivered by God to humans in order to work on their world by representing 7

8 Him the best they can. Consequently, I would define prayer as the primary 8

9 tool (or step) with which the Christian works in a process of transformation of 9

10 the world, in the daily labour of production and reproduction of the symbolic 10

11 goods of God. 'Culture' and 'society' thus appear as the raw material in need of 11

12 transformation, analogically to the way the capitalist workers transform material 12

13 into goods in the industrial working process (Tonda, op. cit.). 13

14 In this labour process, the Spirit is a tool invested with an autonomous 14

15 agency by the believer, which results in an inverted symmetric relationship in 15

16 which the Christian himself/herself appears as a tool to be used by the Spirit, 16

17 as Bosse's words illustrate. Prayer is thus comparable to an aesthetic experience; 17

18 that of human beings who become spectators of their own actions; observing 18

19 a supernatural entity working through them and just appreciating the beauty 19

20 of the result. Pentecostals settle around them a collective, material, symbolic 20

21 and linguistic dispositive to presentify God. This disposition allows them to 21

22 supervene in their actions; as active subjects they are able to influence their own 22

23 destiny through prayer, and as passive subjects, they are actor-spectators of a 23

24 world led by the Almighty. There, neither paradox nor contradiction, they find 24

25 in their interaction with non-visible, immaterial beings a solution of continuity 25

26 to assume both positions simultaneously. It is in this double existential posture - 26

27 that of an instrument being at the same time active and passive - that prayer is 27

28 experienced and narrated. ${ }^{19}$ Accordingly, the repeated prayers and their answers, 28

29

18 See Fer, in this volume.

3119 Pascal Boyer (1997), suggesting a cognitivist approach to religious phenomena,

31 considers counterintuitive assertions, leading to interpretive difficulties when one considers

32 the consequences as being the first feature of religious discourse. The anthropologist Albert

33 Piette (1999) suggested that indeed Christianity was full of these types of utterances, starting

34 with the Christian kerygma. This type of articulation between passive and active existential

35 postures in prayer through the mediation of an invisible entity can be considered as taking 35

36 place in the assertions Pascal Boyer identified as lying at the ground of religions. Besides, 36

37 the invisibility of the entity, or its immateriality, might be a resourceful feature to subsume

37 potential contradictions. Indeed, being invisible and immaterial, it can be as plastic as one

38 wishes and adopt a priori 'contradictory' (they are only contradictory in our thought) traits

39 without being endangered in its foundation. 
1 if there are any, constitute a means to draw an aestheticised style of life, in the 1

2 sense this expression is used by Foucault (1994: 535), an initiative of the self to 2

3 transform the self. Here the transformation is made through an invisible entity, 3

4 as we saw in the case of Bosse when the intervention of the Spirit he invoked 4

5 himself transformed his ethics of responsibility into ethics of conviction on the 5

6 question of the construction of a new orphanage. 6

7

$8 \quad 8$

9 Conclusion 9

$10 \quad 10$

11 Pentecostals are nothing but lovers. Through hearing testimonies and sermons, 11

12 daily conversations and pieces of advice given to one another, the ethnographer 12

13 carrying out Pentecostal fieldwork will be struck by the fact he is observing people 13

14 involved in a love relationship with an absent being: God. Harvey Cox even sees 14

15 there the ground of what he calls a 'Pentecostal theology' - even though some 15

16 scholars might consider this expression to be a sort of oxymoron - in which the 16

17 Lord appears to be a lover playing the game of what Salvatore Cucchiari named a 17

18 'soteriological romance' (1990), in which God tries to court a human being and 18

19 is 'broken-hearted' when the latter does not reply to his advance (see Cox 2001: 19

20 201). As a mere love relationship between two empirical beings is not expressed 20

21 in the same way in every society, so is it for the relationship to the Almighty. 21

22 In the Swedish case, the language of love that glossolalia appears to be requires 22

23 intimacy to be expressed. 23

24 More than teaching us a little bit more on the nature of prayer, the Swedish 24

25 example, parallel to other 'Pentecostalisms', reminds us of the plasticity of 25

26 this transnational religion which changes at the rhythm of its travels through 26

27 national boundaries and with the symbolic work of the actors carrying it out 27

28 and experiencing it in their daily life. As the anthropologist Christophe Pons, 28

29 a specialist of the Icelandic religious context, stated, one should consider 29

30 the contemporary revival movements in a cultural perspective as symbolic 30

31 productions - whereas they are often perceived as 'things apart remaining at the 31

32 limen of cultures without really entering them, because their proper space would 32

33 be the non-places of a globalization without attachments' (Pons 2011b: 26). ${ }^{20} 33$

34 Prayer appears here as a heuristic object, which reveals some of the idiosyncratic 34

35 features of a given society. Indeed, the manifestation of the Spirit in its utterance 35

36 is the result of a work of symbolic production in which the subjects involved 36

37 take into account the constraints imposed by the political and socio-historical 37

$38 \quad 38$

3920 The translation from French is mine. 39 
1 context in which they are inscribed to draw a temporary and always emerging 1

2 regime of religious emotion that will help them to be accepted in their society - 2

3 as well as allowing them to accept a supernatural entity in their daily lives. As the 3

4 Swedish Pentecostals say, the goal is 'to experience the supernatural in a natural 4

5 way' (uppleva det övernaturliga pa naturligt sätt), that is to say that it has to be 5

6 experienced in a way that corresponds to the constraints and negotiated margins 6

7 of freedom they have vis-à-vis their national ('cultural Lutheran') fellows. $\quad 7$

8 The relationship to the Spirit is constructed relative to a given environment 8

9 in an interpretive labour process, producing sense around the self from which 9

10 results a particular style of spiritual manifestation. This process helps define the 10

11 style of prayer, whilst the latter contributes to the transformation of the self and 11

12 of the world as a communication tool with the divine. Through praying, one 12

13 observes human existence reduced to its passive form, for at least a moment, 13

14 however active human beings can be. 14

19 Aronsson, Torbjörn (2005). Guds eld över Sverige. Svensk väckelsehistoria efter 19

20 1945. Uppsala: Livets Ord Förlag. 20

21 Boyer, Pascal (1997). La religion comme phénomène naturel. Paris: Bayard. 21

22 Coleman, Simon (1989). 'Controversy and the Social Order: Response to a 22

23 Religious Group in Sweden'. PhD thesis. University of Cambridge. 23

24 Coleman, Simon (1996). 'The Charismatic Giff', Journal of the Royal 24

25 Anthropological Institute 10: 421-42. 25

26 Coleman, Simon (2006). 'When Silence isn't Golden: Charismatic Speech and 26

27 the Limits of Literalism, in Engelke, Matthew and Tomlinson, Matt (eds), 27

28 The Limits of Meaning, Case Studies in the Anthropology of Christianity. 28

29 Oxford: Oxford University Press, 39-63. 29

30 Coleman, Simon (2007 [2000]). The Globalisation of Charismatic Christianity. 30

31 Spreading the Gospel of Prosperity. New York: Cambridge University Press. 31

32 Corten, André and Mary, André (2000). 'Introduction', in Corten, André and 32

33 Mary, André (eds), Imaginaires politiques et pentecôtismes. Afrique/Amérique 33

34 latine. Paris: Karthala, 11-33. 34

35 Corten, André and Marshall-Fratani, Ruth (2001). Between Babel and Pentecost. 35

36 Transnational Pentecostalism in Africa and Latin America. Bloomington and 36

37 Indianapolis: Indiana University Press. 37

$38 \quad 38$

$39 \quad 39$ 
1 Cox, Harvey (2001 [1995]). Fire from Heaven. The Rise of Pentecostal Spirituality 1

2 and the Reshaping of Religion in the Twenty-First Century. Cambridge, MA: 2

3 Da Capo Press. 3

4 Cucchiari, Salvatore (1990). 'Between Shame and Sanctification: Patriarchy 4

5 and Its Transformation in Sicilian Pentecostalism', American Ethnologist 5

6 17:687-707. 6

7 Elias, Norbert (1973 [1969]). La civilisation des mours. Paris: Calmann-Levy. 7

8 Foucault, Michel (1994). Dits et écrits, vol. IV. Paris: Gallimard. 8

9 Gifford, Paul (2001). 'The Complex Provenance of Some Elements of African 9

10 Pentecostal Theology', in Corten, André and Marshall-Fratani, Ruth (eds), 10

11 Between Babel and Pentecost. Transnational Pentecostalism in Africa and Latin 11

12 America. Bloomington and Indianapolis: Indiana University Press, 62-79. 12

13 Harry, Frédérique (2010). 'Les mutations du protestantisme militant en 13

14 Scandinavie. Du mouvement populaire au rencoforcement convictionnel : 14

15 transformaiton structurelle et idéologique des organisations missionnaires et 15

16 des antennes de jeunesse en Norvège et en Suède de 2000 à 2010'. Thèse de 16

17 doctorat. Paris: Université de la Sorbonne. 17

18 Hollenweger, Walter J. (1978). The Pentecostals. Minneapolis: Augsburg 18

19 Publishing House. 19

20 Hunsicker, David (1996). 'John Wesley: Father of Today's Small Group 20

21 Concept?', Wesleyan Theological Journal 31/1: 192-211. 21

22 Laurent, Pierre-Joseph (2000). 'Diabolisation de l'autre et ruses de l'Esprit: les 22

23 Assemblées de Dieu du Burkina Faso', in Corten, André and Mary, André. 23

24 (eds), Imaginaires politiques et pentecôtismes. Afrique/Amérique latine. Paris: 24

25 Karthala, 61-80. 25

26 Mary, André (2000). 'La violence symbolique de la Pentecôte gabonaise', in 26

27 Corten, André and Mary, André (dir.), Imaginairespolitiques etpentecôtismes. 27

28 Paris: Karthala, 143-63. 28

29 Oredsson, Sverker (2007). 'Vad hände före 1971?', in Oredsson, Sverker 29

30 (ed.), Jönköpings kommuns historia. De första 35 åren. Lund: Historiska 30

31 Media, 13-49. 31

32 Piette, Albert (1999). La religion de près. L'activité religieuse en train de se faire. 32

33 Paris: Métailié. 33

34 Piette, Albert (2003). Le fait religieux. Une théorie de la religion ordinaire. 34

35 Paris: Economica. 35

36 Pons, Christophe (2011a). 'Jésus aux îles Féroé, ou comment se réinvente 36

37 la relation au divin', in Houdart, Sophie and Thiery, Oliver (eds), 37

38 Humains, non-humains. Comment repeupler les sciences sociales. Paris: La 38

39 Découverte, 339-49. 
1 Pons, Christophe (2011b). Les liaisons surnaturelles. Une anthropologie du 1

2 médiumnisme dans l'Islande contemporaine. Paris: Editions CNRS. 2

3 Riis, Ole and Woodhead, Linda (2010). A Sociology of Religious Emotions. 3

4 Oxford: Oxford University Press. 4

5 Sundstedt, Alfred (1969). Pingstväckelsen - dess uppkomst och första 5

6 utvecklingsskede. Stockholm: Normans Förlag. 6

7 Tonda, Joseph (2002). La guérison divine en Afrique centrale (Congo, Gabon). 7

8 Brazzaville: Karthala. 8

9 Åberg, Göran (2007). 'Kyrkor och Samfund', in Oredsson, S. (ed.), Jönköpings 9

10 kommuns historia. De forsta 35 åren. Lund: Historiska Media, 277-311. 10

11

$12 \longrightarrow 12$

$13-13$

$14+14$

$15-15$

$16 \longrightarrow 16$

$17-17$

$18-18$

$19-19$

$20-20$

$21-21$

$22-22$

$23-23$

$24 \quad 24$

$25-25$

$26-26$

$27 \longrightarrow 27$

$28 \longrightarrow 28$

$29>29$

$30-30$

$31-31$

$32 \quad 32$

$33-33$

$34-34$

$35-35$

$36 \quad 36$

$37 \quad 37$

$38-38$

$39-39$ 